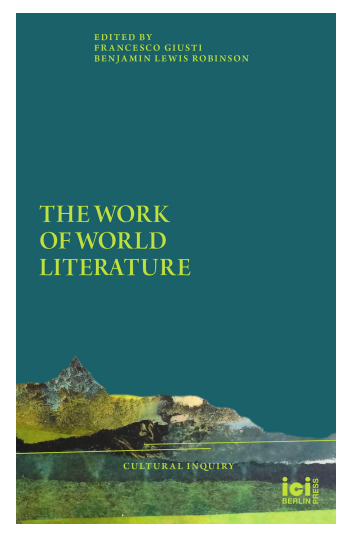

The Work of World Literature, ed. by Francesco Giusti and Benjamin Lewis Robinson, Cultural Inquiry, 19 (Berlin: ICI Berlin Press, 2021), pp. 25-56

\section{DEREK ATTRIDGE}

\section{Untranslatability and the Challenge of World Literature}

\section{A South African Example}

\author{
CITE AS:
}

\begin{abstract}
Derek Attridge, 'Untranslatability and the Challenge of World Literature: A South African Example', in The Work of World Literature, ed. by Francesco Giusti and Benjamin Lewis Robinson, Cultural Inquiry, 19 (Berlin: ICI Berlin Press, 2021), pp. 25-56 <https://doi.org/10.37050/ci-19_02>
\end{abstract}

RIGHTS STATEMENT:

(C) by the author(s)
This work is licensed under a Creative Commons Attribution-
ShareAlike 4.0 International License.

ABSTRACT: What are called 'natural languages' are artificial, often politically instituted and regulated, phenomena; a more accurate picture of speech practices around the globe is of a multidimensional continuum. This essay asks what the implications of this understanding of language are for translation, and focuses on the variety of Afrikaans known as Kaaps, which has traditionally been treated as a dialect rather than a language in its own right. An analysis of a poem in Kaaps by Nathan Trantraal reveals the challenges such a use of language constitutes for translation. A revised understanding of translation is proposed, relying less on the notion of transfer of meaning from one language to another and more on an active engagement with the experience of the reader.

KEYWORDS: Language; dialect; translation; untranslatability; Afrikaans; Kaaps; world literature 


\title{
Untranslatability and the Challenge of World Literature
}

\author{
A South African Example \\ DEREK ATTRIDGE
}

WHAT IS A LANGUAGE?

Serbo-Croatian no longer exists. Having been acknowledged by this name for well over a century and spoken by some sixteen or seventeen million people, the language disappeared without trace when the state of Yugoslavia disappeared. It was replaced by four separate languages, Serbian, Croatian, Bosnian, and, more recently, Montenegrin. Of course, the inhabitants of these four countries didn't start speaking differently at this moment in history, and they continue to understand one another without difficulty, but

\footnotetext{
* Research carried out at the Stellenbosch Institute for Advanced Study (STIAS), Wallenberg Research Centre at Stellenbosch University, Stellenbosch 7600, South Africa.
} 
nationalist sentiment prohibits the idea of a single language with four (or more) dialects - or, more accurately, a continuum of language use over the entire geopolitical area, and to some degree across its borders, permitting mutual intelligibility. Thus a comment on a BBC website can claim, in defiance of linguistic history, that these new languages 'have separate histories, developments, origins and most importantly identities. Even though they can be mutually understood by its speakers, they are not and cannot be one language [...] The term "Serbo-Croatian" is a communistic fantasy language which existed only on paper.' ${ }^{1}$

This example makes the political basis of what we call 'natural languages' strikingly evident, and a similar picture could be drawn by looking at actual language use in many parts of the globe. ${ }^{2}$ Whatever the origin - and it's disputed - of the saying 'A language is a dialect with an army and a navy', it captures nicely the political and hegemonic determination of those systems of speech we unthinkingly call 'languages'. Enshrined in the doxa, and operative in many scientific spheres, is the view that the domain of

1 Marjina, “'Serb-Croation” is a Communistic Fantasy Language', in 'Your Say - Language and Identity', BBC <http://www.bbc.co.uk/ languages/yoursay/language_and_identity/serbiancroatianbosnian/ serbocroatian_is_a_communistic_fantasy_language.shtml> [accessed 27 August 2019].

2 A good example is the co-existence of languages called 'Urdu' and 'Hindi': Aamir Mufti observes that '[p] art of the difficulty of making this argument about Hindi-Urdu as a spectrum, which is instinctually evident at various levels to native speakers, is that there is no name for this more encompassing and contradictory linguistic formation - whether Hindi, Urdu, or Hindustani - that is not subject to the terms of the conflict itself: Indian and Pakistani speakers, for instance, routinely use 'Hindi' and 'Urdu' respectively, to refer to exactly the same common speech forms', in Aamir R. Mufti, Forget English! Orientalisms and World Literatures (Cambridge, MA: Harvard University Press, 2016), p. 120. 
language - le langage in Saussure's classification - consists of distinct, named, languages - les langues - as the unmarked, 'natural', entities, and that there are subsidiary, and often less prestigious, variants that can't be classified in this way and are marked as 'dialects'. Samuel Weber describes the reality with his customary perspicacity:

\begin{abstract}
Usually, the linguistic systems between which translations move are designated as 'natural' or 'national' languages. However, these terms are anything but precise or satisfactory. 'Portuguese,' for instance, although named for a specific nation, is no more a 'national' language than is 'English,' 'French,' 'German' or 'Spanish.' Yet, to call these languages 'natural' is perhaps even more unsatisfactory than to designate them as 'national.' The imprecision of such terms is in direct proportion to the linguistic diversity they seek to subsume. ${ }^{3}$
\end{abstract}

A more accurate account, then, would be that the domain of natural language - which we may think of as the global totality of the psychological mechanisms and internalized lexicons enabling speech - is a multidimensional continuum, and that it is the distinct, named, languages that are artificial and marked. ${ }^{4}$

3 Samuel Weber, 'A Touch of Translation: On Walter Benjamin's “Task of the Translator"', in Nation, Language, and the Ethics of Translation, ed. by Sandra Bermann and Michael Wood (Princeton, NJ: Princeton University Press, 2005), pp. 65-78 (p. 66). Emily Apter, also quoting from Weber's essay and building on the work of Edouard Glissant, argues that Creole, understood as a loose umbrella term for language varieties that don't sit easily under standard language names, 'denaturalizes monolingualization, showing it to be an artificial arrest of language transit and exchange' (The Translation Zone: A New Comparative Literature (Princeton, NJ: Princeton University Press, 2006), p. 245).

4 Naoki Sakai makes the interesting suggestion that languages are not empirically verifiable but operate like Kantian regulative ideas, in 'How Do We Count a Language? Translation and Discontinuity', Translation Studies, 2 (2009), pp. 71-88. 
Each of these named languages has a singular history, usually with a political dimension, arising from the domination of one group over others and often part of a nationalistic endeavour. ${ }^{5}$ (The affirmation of a named language can contribute to a movement of resistance against a hegemonic power, such as the promotion of Irish in the early twentieth century and the current campaign on behalf of Catalan; though if a resistance movement of this type is victorious it inevitably continues to champion the language as a unifying nationalist instrument.) The establishment of a written form of the language with an agreed orthography is frequently part of the process, as is the creation of dictionaries and grammars; writers of literary works, too, can play an important role in the promotion and stabilization of a language, a well-known example being Dante's choice of the Tuscan dialect for the Commedia.

If we think not in terms of discrete languages but in terms of speech communities, we can reconceptualize global linguistic variation as a matter of groups of individuals each of whose use of language is intelligible within the group. Such communities are porous, overlap with one another, and are subject to continual change as a result of movement and interaction. They can also be seen to exist at various levels: members of a small group may be able

5 George Steiner follows Herder in advancing a strong version of the commonplace idea that languages themselves possess an identity: 'I am suggesting that the outwardly communicative, extrovert thrust of language is secondary. [...] The primary drive is inward and domestic. Each tongue hoards the resources of consciousness, the world-pictures of the clan. [...] [A] language builds a wall around the "middle kingdom" of the group's identity. It is secret towards the outsider and inventive of its own world', in After Babel: Aspects of Language and Translation, 3rd edn (Oxford: Oxford University Press, 1998), p. 243. A less naïve view is reflected in Benedict Anderson's discussion of the role of 'languages-of-state' in nineteenth-century European nationalisms in Imagined Communities, 2nd edn (London: Verso, 1991), ch. 5. 
to communicate with one another in a thoroughgoing and detailed way but with members of a larger group in a more limited manner - this might be the case for a speaker of Swedish in the context of Scandinavia, say. Even the family can operate in this way, achieving an intimacy of communication impossible in wider groups. The speech practices of a particular individual constitute a unique idiolect, that is to say, a singular combination of the elements conventionally regarded as belonging to specific languages or dialects. ${ }^{6}$ An individual's idiolect is the product of a unique personal history, usually involving exposure to several kinds of speech practice; one can think of it as an aspect of what I've called the individual's idioculture, the particular constellation of knowledge, memories, presuppositions, habits, abilities, prejudices, tastes, affective tendencies, and so on operative at any one time to constitute the subject. (An idiolect is not the same as a 'private language'; every element in an idiolect is shared, though not necessarily all elements are shared with the same group of speakers, and the same is true of an idioculture, which is a way of looking at subjectivity as an open, cultural process rather than the closed entity suggested by terms like 'self' or 'individual' or, for that matter, 'subject'.) A spontaneous utterance will usually reflect its author's idiolect, though certain types of written text are designed to minimize idiolectal features. ${ }^{7}$

6 The term is not always understood by literary critics. Rebecca Walkowitz's use of it, for instance, is hard to distinguish from 'dialect'; thus the work of Chang and Voge is said to be 'full of idiolect', in Born Translated: The Contemporary Novel in an Age of World Literature (New York: Columbia University Press, 2015), p. 220.

7 Some interpretations of idiolect continue to rely on a conventional notion of language: an idiolect is regarded as the version of a language spoken by an individual. I am using it to designate the totality of an individual's language knowledge and habits, which may include the ability to speak one or more languages in the conventional sense. 
Though the idea that languages do not exist except as constructions that are artificial, after the fact, and often political in origin goes against common assumptions, it's not news to linguists who study language variation. In the standard textbook on dialectology, Chambers and Trudgill explain that 'a "language" is not a particularly linguistic notion at all': 8 they speak instead of 'dialect continua' linked by a chain of mutual intelligibility between neighbouring areas. Examples are the West Germanic continuum, including what we call German, Dutch, and Flemish, and the Scandinavian continuum, comprising Norwegian, Swedish, and Danish, itself part of the North Germanic continuum. The languages that were once subsumed under the label Serbo-Croatian are all part of the South Slavic continuum, which also includes Macedonian and Bulgarian. A similar picture emerges in most parts of the world, with social distinctions playing a part in addition to geographical spread in producing continua. The stronger the nationalist agenda of the state power, the more likely there will exist something like a language, enshrined in grammars and dictionaries and often policed by an academy.

My example today is the South African language or the particular section of the West Germanic continuum - we know as 'Afrikaans' (which simply means 'African', and derives from the older term 'Afrikaans-Hollands', that is, 'African Dutch', to distinguish it from the Dutch of the Netherlands). But first I want to give some attention to the consequences for literary study, and, more particularly literary translation, of acknowledging the reality of language use as I have described it.

8 J. K. Chambers and Peter Trudgill, Dialectology, 2nd edn (Cambridge: Cambridge University Press, 1998), p. 4. 
Robert Young, in an important article titled 'That Which Is Casually Called a Language', argues that

\begin{abstract}
the idea of a language, and of languages in a sociocultural sense, is altogether a Western construction, part of the same process whereby Europeans produced indigenous law from custom, races and castes from ethnological or anthropological semiotics, or cultures from varieties of social institutions and human behaviour. ${ }^{9}$
\end{abstract}

Young points out that even the well-intentioned promotion of 'multilingualism' relies on a notion of 'separate, classifiable, and classified single languages, each of which by definition is marked by a border that ensures unity, like the boundary of a nation', and argues that '[i]n considering the idea of world literature, we need to reflect on the history of the construction of languages and to question any assumption of an intrinsic relation between languages and geographic location or ethnic, indigenous, or other identity. ${ }^{10}$

Central to any conception of 'world literature' is translation. One of the most influential definitions, that of David Damrosch, includes the statement, 'World literature is writing that gains in translation', and Damrosch insists that 'the study of world literature should embrace translation far more actively than it has usually done to date. ${ }^{11}$

9 Robert Young, 'That Which Is Casually Called a Language', PMLA, 131.5 (2016), pp. 1207-21 (p. 1208). Young gives examples of theorists - e.g. Trubetzkoy and de Courtenay - who resist the usual model.

10 Ibid., p. 1209.

11 David Damrosch, What Is World Literature? (Princeton, NJ: Princeton University Press, 2003), pp. 288-89. Nicholas Harrison presents a telling critique of this claim in 'World Literature: What Gets Lost in Translation?', Journal of Commonwealth Literature, 29 (2014), pp. 411-26. 
An alternative view would be that translation is something like a necessary evil in avoiding the conception of 'world literature' as simply the totality of non-communicating literary traditions. In either case, the work of translators is unavoidable in making up for the inevitable limitations of readers. Young perhaps overstates the case in suggesting that the practice of translation only emerged when the idea of separate languages became established, and that 'the whole point of translation is to keep languages apart. [... Not to carry meaning across languages but to confirm the presumption of the division between them, ${ }^{12}$ but it's surely correct that the current dominant conception of translation relies on, and helps to entrench, the notion that languages are discrete and self-contained. A text in source language $a$ is translated into a text in target language $b$, and the translated text is roughly the same length as the original text. Saussure's highly influential positing of langue, the autonomous system held at any given time in the minds of a language community, as the proper object of linguistic study, does nothing to dispel this idea, and, through his positing of the science of semiotics, extends it to other cultural sign-systems.

The question I wish to address is this: How does our conception of translation, and therefore of world literature, change if we revise our understanding of language so as to give full weight to the spectrum of human linguistic activity and to acknowledge the historical and politicallyinfluenced character of named languages? I want to tie this question to the issue of literary experience, which includes the pleasure we take in literary works, the responsibility we are under as readers to do justice to the work's singularity, and the ontological status of the work as event. 
One way of approaching these questions is to ask how the procedures of translation have to change when the source text is not in a named language but occupies a place in the continuum at which the resources of more than one of those languages are drawn on. The challenge of translating a text in which two or more languages are used has often been discussed; long passages of War and Peace, for instance, are in French - does the translator leave them in French, assuming the reader will cope in the same way that Tolstoy assumed the Russian reader would cope, or translate them into the target language, resulting in the disappearance of their linguistic distinctiveness? One reason for the impossibility of translating Finnegans Wake is the multiplicity of tongues in which it's written: it can be seen, in fact, as Joyce's full-blown attack on the idea of separate languages. Jacques Derrida selected a phrase of two words from the Wake - 'he war' - to spell out the difficulties that arise for translation, stressing that what the translator is dealing with is an event:

To translate 'he war' into the system of a single language - as has just been tried in French ('et il en fut ainsi') - is to erase the event of the mark, not only what is said in it but its very saying and writing, the mark of its law and the law of its mark. The current concept of translation is still regulated according to the twice one, the operation of passing from one language into another, each of them forming an organism or a system the rigorous integrity of which remains at the level of supposition, like that of a body proper. ${ }^{13}$

Finnegans Wake may be a limit-text but, as I've argued in another context, it may also be seen as an extreme that reveals

13 Jacques Derrida, 'Two Words for Joyce', in Post-structuralist Joyce: Essays from the French, ed. by Derek Attridge and Daniel Ferrer (Cambridge: Cambridge University Press, 1984), pp. 145-59 (p. 156). 
the nature of the centre: any literary text, in so far as it is literary in the fullest sense, challenges the constraints that arise from a conception of a language as an autonomous body. ${ }^{14}$ My question can be generalized further, then: what would the consequences be of taking non-standard languages and cultures (what would conventionally be called 'mixed' languages and cultures) as the norm of speech practice rather than the standard, named, languages?

\section{AFRIKAANS, ENGLISH, AND KAAPS: A POETIC EXAMPLE}

The Afrikaans language is one of the world's youngest. It descends from the Dutch of the original colonial power in South Africa - the first ships arrived at the Cape of Good Hope in 1652 - but bears the traces of a number of other languages into which its speakers came into contact, including indigenous languages and those of slaves imported from the East. Beginning in the eighteenth century, a relatively stable version of the linguistic mixture gradually emerged, derived at least in part from the simplified version of Dutch used by the slaves and by their masters in speaking to them. ${ }^{15}$ (The earliest written documents in what is recognizably Afrikaans were in Arabic script.) The establishment and recognition of Afrikaans became a polit-

14 Derek Attridge, 'Deconstructing Digression: The Backbone of Finnegans Wake and the Margins of Culture', chapter 8 of Peculiar Language: Literature as Difference from the Renaissance to James Joyce (Ithaca, NY: Cornell University Press, 1988).

15 The origin and history of Afrikaans remains subject to debate; Wannie A. M. Carstens and Edith H. Raidt, in Die Storie van Afrikaans: Uit Europa en van Afrika (Pretoria: Protea Boekhuis, 2017), provide a table showing 19 different theories (pp. 428-30). One reason for the many different accounts is that the myth of the 'pure' language requires an appropriate origin story, which may not correspond to the factual evidence. 
ical project in the nineteenth century: the 'Genootskap van Regte Afrikaners' (or Fellowship of True Afrikaners) was formed in 1875 , and set to work creating the dictionaries and grammars needed to constitute the new way of speaking and writing as a language in its own right, clearly distinguishable from Dutch. Formal recognition (but only as a 'variety of Dutch') was achieved with the passing of the Official Languages of the Union Act of 1925. Of the types of Afrikaans that existed at that time, preference was given to 'Oosgrensafrikaans' (Eastern border Afrikaans), the language of the Boer republics, in preference to 'Kaapse Afrikaans' (Cape Afrikaans, to which I'll return) and 'Oranjerivierafrikaans' (Orange River Afrikaans, influenced more strongly by the indigenous Khoi languages). Eventually, the 1961 Constitution of the newly-declared Republic of South Africa demoted Dutch and made Afrikaans one of the two official languages with English. (As a footnote: the arrival of democracy in 1994 meant the recognition of eleven official languages.)

Part of the unacknowledged rationale for the project of establishing a 'true' Afrikaans was the fact that the language spoken by the white descendants of European immigrants was worryingly close to the language spoken by the people known as 'Coloureds' - many of them the descendants of slave-women impregnated by their Dutch-speaking masters. So Afrikaans had to be instituted and safeguarded as a pure language spoken by white people, and differentiated from the similar language spoken by those who were not white. One way of doing this was to exclude 'anglicisms', thus establishing a clear difference between white Afrikaans and the version spoken by the Coloured community (largely in the area around Cape Town and on the West Coast), which did not operate any such exclu- 
sion. Members of this community frequently drew, and continue to draw, on English vocabulary in their speech, giving it a distinctive lexical character in combination with a distinctive pronunciation. The white version of Afrikaans was promoted and regulated by the Afrikaner Nationalist government that came to power in 1948, and Afrikaans writers did much to create the norms of the language and give it richness and prestige. The speech of the Cape Coloured community, lacking an army and a navy, could then be safely classified as a mere 'dialect' of Afrikaans. ${ }^{16}$

One might think, and many in South Africa did and perhaps still do think, that this so-called 'dialect' is the first language of fewer speakers than Afrikaans 'proper', but the reverse is the case. Afrikaans - in all its varieties - is spoken as a first language by around seven million people, and some $60 \%$ of these Afrikaans speakers would have been classified as 'non-white' under apartheid. ${ }^{17}$ In the light of what I have been saying, it's of course a simplification to assert that there are just two types of Afrikaans, sharply distinct from one another; continua exist among both white and non-white speakers as well as between the two groups. But thanks to the efforts of the Afrikaans Taalkommissie (Language Commission) of the Akademie vir Wetenskap en Kuns (Academy for Science and Arts) the historically white version of the language has relatively

16 For a useful account of the history of Afrikaans that stresses the role played by non-white speakers, see Menán van Heerden, 'Afrikaans: The Language of Black and Coloured Dissent', South African History Online < https://www.sahistory.org.za/article/afrikaans-language-blackand-coloured-dissent $>$ [accessed 27 August 2019].

17 See the figures from the 2011 census (the most recent) at <http://www.statssa.gov.za/census/census_2011/census_products/ Census_2011_Census_in_brief.pdf $>$, p. $\overline{26}$ [accessed 27 August 2019]. For a comprehensive account of South Africa's languages, see Language in South Africa, ed. by Rajend Mesthrie (Cambridge: Cambridge University Press, 2002). 
well-defined boundaries. It's often referred to as 'standard Afrikaans' ('Standaardafrikaans'), but to give it this name is to perpetuate the implication that it's the unmarked form and all other varieties are dialects. The Afrikaans spoken in the Coloured community of the Cape, often referred to as 'Kaapse Afrikaans', 'Afrikaaps', or simply 'Kaaps' (though its speakers mostly just think of it as Afrikaans) lacks a governing academy and is not enshrined in scholarly publications such as dictionaries. ${ }^{18}$ Few literary works have employed it (though the picture is changing). ${ }^{19}$

Though there is no standard form of Kaaps - different speakers will use more or less English, for example, and do so for different purposes and in different situations and no fixed orthography, the positing of a distinct language with its own name is an important weapon in the struggle to acknowledge the speech habits of this section of the population as equal to those of white Afrikaners which is, of course, also a struggle to gain respect for the culture of this community. I shall therefore follow suit in referring to Kaaps as a language, in spite of my reservations about the identification of separate languages. As was the case with 'white' Afrikaans, writers using Kaaps — which is primarily a spoken language — have played and will continue to play a crucial role in securing for Kaaps the prestige and stability it needs. As Rebecca Walkowitz, summarizing what she calls 'the celebration of the untranslatable', puts it, 'By using nonstandard versions of a national language, a work opposes political and cultural homogenization, both

18 Coloured children are taught 'standard Afrikaans' at school, however, though some literature in Kaaps may be studied.

19 The most significant writer using Kaaps during the apartheid years was Adam Small (1936-2016), whose plays and poems in the language revealed the rich resources it offered. See <https://www.litnet.co.za/ adam-small-1936/> [accessed 27 August 2019]. 
the kind imposed by other speakers of that language and the kind imposed by translators and publishers. ${ }^{20}$

One of the newer writers to make use of Kaaps is Nathan Trantraal. Born in Cape Town, he is the author of three collections of poems and a graphic novel. I have selected one of the poems that appeared in 2013 in his debut collection, Chokers en survivors, ${ }^{21}$ in which Trantraal developed an orthography to reflect the pronunciation of Kaaps and captured the manner in which English words and phrases pepper the primary use of Afrikaans. ${ }^{22}$ (Linguists call this process 'code-switching', a term which, of course, perpetuates the idea that languages are completely separate, existing as distinct systems in the brain.) Notice, by the way, that speakers of Kaaps operate two phonological systems: English words are pronounced as English, Afrikaans words as Afrikaans, both in a distinctive accent.

\author{
Woensdag, sestien Februarie neëntien-ag-en-tagtig \\ Ek is nog klein. \\ Ek staan allien innie agtejaat \\ by my ouma-hulle hys en ek voel sad \\ omdat ek wiet vandag isse boring, unimportant dag. \\ Ek wiet die dag het niks gedoen \\ wattit worthy maak om onthou te wôtie. \\ Ek voel sad omdat ek wiet daa was al dysende dae \\ soes dié wat ek al kla vegiet et. \\ 'n Mens kyk trug op jou liewe ennie goed wat ytstaan, \\ dai is vi jou jou liewe.
}

20 Walkowitz, Born Translated, p. 32.

21 Nathan Trantraal, Chokers en survivors (Cape Town: Kwela Books, 2013). Trantraal has published two further collection of poems, Alles het niet kom wôd and Oolog (Cape Town: Kwela Books, 2017 and 2020). $\mathrm{He}$ is also the author of a collection of stories written in Kaaps, Wit issie 'n colour nie (Cape Town: Kwela Books, 2018).

22 Brian Lennon discusses such 'plurilinguistic texts' in In Babel's Shadow: Multilingual Literatures, Monolingual States (Minneapolis: University of Minnesota Press, 2010). 
Maa dai issie die liewe nie.

Dai issie highlights reel.

Jou liewe isse klom dae wat niks gebee nie.

Ek stap narrie wasgoed wat oppie lyn hang, ek sit my hand tien 'n nat handdoek en ek dink ek gaan nooit die dag vegietie.

To provide some sense of how far the language of the poem deviates from 'correct' Afrikaans, here's a version in which I've ironed out the 'irregularities' as well as the instances of English. ${ }^{23}$ Most of these irregularities are there to reflect the typical pronunciation of a speaker of Kaaps. For instance, a distinctive feature of Afrikaans syntax is its handling of negatives: all negative words, such as 'niks' and 'nooit' - 'nothing' and 'never' - are followed at the end of the sentence by 'nie'; in the Kaaps represented in Trantraal's poetry, this is reduced to '-ie' at the end of the word, as in 'wôtie' and 'vegietie'. In this version, I've restored 'nie' where appropriate.

\section{Woensdag, sestien Februarie neëntien-ag-en-tagtig}

Ek is nog klein.

Ek staan alleen in die agterplaas

by my ouma-hulle se huis en ek voel hartseer

omdat ek weet vandag is 'n vervelige, onbelangrike dag.

Ek weet die dag het niks gedoen

wat dit die moeite werd maak om onthou te word nie.

Ek voel hartseer omdat ek weet daar was al duisende dae soos dié wat ek reeds klaar vergeet het.

'n Mens kyk terug op jou lewe en die goed wat uitstaan, daardie is vir jou jou lewe.

Maar daardie is nie die lewe nie.

Daardie is die hoogtepunte spoel.

Jou lewe is 'n klomp dae waarin niks gebeur nie.

23 My thanks to Imke van Heerden, Heinrich Gerwel, and Andrew van der Vlies for their assistance in this process. 
Ek stap na die wasgoed wat op die lyn hang, ek sit my hand teen 'n nat handdoek en ek dink ek gaan nooit die dag vergeet nie.

If poetry like this is going to be appreciated beyond a very narrow circle, and its political importance registered, it needs to be translated. How are we going to translate this poem for an Anglophone readership? There is no version of English that I know of that could capture a similar use of the words of a different language, and no way the difference in cultural prestige between the principal language and the secondary language could be replicated. (I suspect it would be difficult in any language.) In the following version, I've simply translated the non-English words into English, and left the English words as they are.

Wednesday, 16 February 1988

I am still little.

I am standing alone in the back yard at my grandma and them's house and I feel sad because I know today is a boring, unimportant day.

I know the day has done nothing that makes it worth remembering.

I feel sad because I know there have already been thousands of days

like those I have already completely forgotten.

A person looks back on your life and the things that stand out:

That, for you, is your life.

But that isn't life.

That is the highlights reel.

Your life is a bunch of days when nothing happens.

I walk to the washing hanging on the line,

I put my hand against a wet towel and I think I am never going to forget this day.

I think it works fairly well as a poem in English, conveying the thoughts of a child grappling with the sense of a 
past made up of unmemorable days leading up to yet another unmemorable day - and then finding that this day has turned into a memorable day precisely through the thinking of those thoughts. The hints of an impoverished childhood (which are much stronger in many of Trantraal's other poems) - the boredom, the lack of stimulation as he hangs about in his grandmother's back yard, and the washing on the line - contribute to the value of the discovery at the end of the poem. And the sensory vividness of the wet towel, the arbitrariness of which contributes to the poem's realism at this point, is part of the child's experience of unexpected significance.

But the losses are great in this version: there's none of the colloquial tang that suggests a particular environment, social class, and - this being South Africa - racial community. Part of the reason for Trantraal's success is his challenge to the pieties of Afrikaner linguistic purism: for white Capetonians to see the language they hear on the street every day given the status of print in a poetry collection constitutes, for many, a surprise (pleasant or unpleasant), and for Coloured readers of poetry, it's an affirmation of the value of their discourse and culture. Trantraal is on record as complaining that Adam Small used the language largely for comic purposes, ${ }^{24}$ and although he himself does the same in many of his poems, this example shows how it can participate in something that may be light in tone but has real depth. ${ }^{25}$ And, of course, the translation loses

24 Small in fact played an important role in promoting the dignity and standing of Kaaps. 'Kaaps is nie 'n grappigheid of snaaksigheid nie, maar 'n taal' (Kaaps is not a joke or a comedy, but a language), he insists in the Introduction to the revised edition of his poetry collection Kitaar my Kruis (Cape Town: Hollandsche Afrikaansche Uitgewers Maatschappij, 1973), p. 9.

25 The use of Kaaps for non-comic purposes is illustrated by Olivia M. Coetzee's project of Bible translations published on Litnet 
entirely the sense of an inbetween way of speaking, neither fully Afrikaans nor English, and it can't avail itself of the resource constituted by the availability of two vocabularies, with different connotations, to draw from.

How, then, could we bring to the translation some of the qualities imparted by the use of Kaaps? An attempt to replicate in English the 'nonstandard' features of the original has been made by Alice Inggs: ${ }^{26}$

\section{Wednesday, 16 February 1988}

I am still small.

I stand alone inna backyard at my granma-and-them's house and I feel sad becos I no today issa boring, unimportant day.

I no the day has done nothing that make it worthy of remembering.

I feel sad becos I no there were alredy thousands of days

<https://www.litnet.co.za/category/nuwe-skryfwerk-new-writing/ bybelinkaaps/> [accessed 27 August 2019]. It is noticeable, however, that Coetzee very rarely draws on the tendency of Kaaps-speakers to use English words. (In her own account of her project, she does so more freely: 'Waarom die Bybel in Kaaps?' (Why the Bible in Kaaps?) <https://www.litnet.co.za/waarom-die-bybel-kaaps/> [accessed 27 August 2019].) The free use of English in a largely Afrikaans context is evidenced in Marlene van Niekerk's hard-hitting play, Die Kortstondige raklewe van Anastasia W (The brief shelf-life of Anastasia W) (Script published with CD, issued by Teaterteater, 2010); my thanks to Hannes van $\mathrm{Zyl}$ for providing me with a copy of this work.

26 Nathan Trantraal, 'Wednesday, 16 February 1988', trans. by Alice Inggs, Asymptote <https://www.asymptotejournal.com/poetry/ nathan-trantraal-chokers-en-survivors/> [accessed 27 August 2019]. Another poet who uses Kaaps is Trantraal's wife, Ronelda Kamfer; her first collection, Noudat slapende honde (Now that sleeping dogs), appeared in 2008, her second, Hammie, in 2106; both published by Kwela Books in Cape Town. Several of her poems appear in the bilingual anthology, In a Burning Sea, ed. by Marlise Joubert (Pretoria: Protea House, 2014) with translations by Charl J. F. Cilliers. Cilliers does not attempt to find an equivalent for Kamfer's 'non-standard' Afrikaans, but uses straightforward English with a couple of untranslated slang words, one of which is explained in a footnote. 
lyk this that I have alredy fo'gotten.

A person looks back on your life anna things that stand owt,

fo you that is your life

But that isn't living,

That's the highlights reel.

Your life issa stack of days when nothing happened.

I walk to the washing hanging onna line,

I put my hand gainst a wet towel

and I think I am neva gonna fo'get this day.

There are a number of problems with this worthy attempt. For instance, Inggs makes the mistake of confusing spelling mistakes with variant pronunciation. Trantraal spells 'weet' - 'know' - as 'wiet' because this is an accurate representation, using the phonetic rules of Afrikaans, of a Kaaps pronunciation; but Inggs's 'becos' for 'because', 'no' for 'know', and 'alredy' for 'already' (to mention only three examples) produce no difference in pronunciation unless one already knows the Kaaps accent - in which case the spelling change is redundant. Trantraal's poem captures the voice of a distinct and distinctive community; but it's hard to know what kind of English Inggs's version is meant to represent.

What is to be done, then, to convey to a non-Afrikaans speaking reader or listener the power and subtlety of this poem and the pleasures it has to offer? I hope I have done a little of this already, in providing several versions and commenting on them; every individual will have been able to appreciate some aspects of the poem, depending on their own idiolect and idioculture. A further strategy would be to go through the original poem with further comments. If, as I have argued elsewhere, the literary is constituted by the experience of readers, a translation that succeeded only in conveying the semantic dimension of a text would be failing to treat it as a literary work, so this process is not 
simply one of clarifying meaning but also of looking for ways of conveying that experience. ${ }^{27}$

We may look at the first few lines.

Ek is nog klein.

- 'I am still little' — the historic present plunges us directly into the mind of a child;

- 'klein' - I have suggested 'little' rather than 'small', since the former is more associated with age than the latter, and 'klein' is common in references to children;

- 'nog' - still: in other words, I have not yet grown up, and am aware of this fact.

Ek staan allien innie agtejaat

- 'I am standing alone in the back yard'. Now we hear the distinctive voice of the Coloured speaker: the diphthong in 'alleen' disappears in 'allien'; the two words 'in die' become one in 'innie';

- 'agtejaat' is not as correct as 'agterplaas' - this suggests the influence of the English 'yard.'

by my ouma-hulle hys en ek voel sad

- 'at my grandma and them's house and I feel sad' ' $\mathrm{x}$-hulle' is common colloquialism in Afrikaans, only partially captured in the English 'and them';

27 See Derek Attridge, The Singularity of Literature (London: Routledge, 2004) and The Work of Literature (Oxford: Oxford University Press, 2015), passim.

28 The massive Reader's Digest Afrikaans-Engels Woordeboek/English-Afrikaans Dictionary reflects the authority of the Taalcommissie: 'jaard, jaards, jaardjie: these English borrowings are not standard Afrikaans, although many unsophisticated speakers use them. Since the Suid-Afrikaanse Akademie has not approved them, they are unacceptable', ed. by Peter Grobbelaar (Cape Town: Reader's Digest Association, 1987), p. 230. 
- 'hys' for 'huis' indicates the Kaaps pronunciation;

- the syntax is characteristic in its omission of the possessive: 'huis' rather than 'se huis';

- 'sad' - a blunt English word; the Afrikaans words are more refined: hartseer, treurig, droewig, swaarmoedig...

omdat ek wiet vandag isse boring, unimportant dag.

- 'because I know today is a boring, unimportant day'. The English words 'boring, unimportant' emphasize those adjectives, conveying the mood with more power than the Afrikaans: their stressed syllables rhyme and can be elongated.

Ek wiet die dag het niks gedoen wattit worthy maak om onthou te wôtie.

- 'I know the day has done nothing | that makes it worth remembering' (literally, 'to be remembered')

- the day becomes the subject of the sentence: it hasn't made itself memorable.

- 'wôtie' combines 'word' and 'nie', the passive 'be' and the second negative required by Afrikaans syntax - with a circumflex to indicate the pronunciation.

- 'worthy': the English word where we might expect 'waardig', or a phrase like 'die moeite werd', perhaps emphasizes the worthiness in question by drawing on the more prestigious language.

The most striking use of an English word in the rest of the poem is 'highlights'; I've suggested 'hoogtepunte' as an Afrikaans alternative, but 'highlights' would be the word 
made familiar by television and recordings, especially in the phrase 'highlights reel', which has outlived the use of tape spools in recording vision and sound. The final section of the poem, whose climactic function is emphasized by the extra space before it, is entirely in Afrikaans; perhaps this is a way of resisting any potential comic qualities of the interpolation of English.

My hope would be that going through the poem like this with a willing auditor would make it possible for such a person to engage with the poem in its original form with understanding and enjoyment. Clearly, the degree to which this could happen would depend in part on the linguistic competence of the individual - someone who knows Dutch would find it quite easy to enjoy the poem, someone with German less so, and someone with only, say, French or Italian, would find it more difficult. This mode of translation is less easy to achieve in print, as my limited comments show; it's not unthinkable, however. For such purposes, the poem would be given in the original as well as in straightforward translation, but with notes and alternatives, all geared to making it possible for the reader to attempt the real thing. The danger would be that the poem might disappear under the commentary, as could be said of Nabokov's translation of Pushkin's Eugene Onegin, in which the notes take up six times the space of the poem; clearly, a balance between helpfulness and overwhelmingness needs to be created.

It will be obvious that part of the challenge for the reader who is not a member of the Cape Coloured community - and I include myself, as a white South African who emigrated fifty years ago — is to understand and appreciate the cultural implications of this use of language, and information about this aspect of the poem 
would also be useful in any edition for readers unfamiliar with Kaaps. Trantraal's primary audience in South Africa is white Afrikaans speakers; given the relative poverty in which the majority of Coloureds live, poetry-reading is not widespread among the community whose language and experiences the poems capture. Trantraal therefore runs the risk of presenting the portraits of his own family and friends, and the anecdotes he relates about life in the Cape Town Coloured township of Bishop Lavis, ${ }^{29}$ as curiosities for the entertainment of those whose lives are very different. The unusual appearance of the language on the page, the mixture of English and Afrikaans, and the colourful lives of the characters portrayed can all too easily be enjoyed as quaint and exotic features of this poetry; a responsible engagement, on the other hand, would be one that registers the real deprivation and suffering the poems chart and appreciates the linguistic complexity not as a comic device but as a reflection of local speech patterns, used as much for the gravest subjects as for light-hearted ones. I see the attempt to understand the disparity between the conditions registered in the poetry and those of most of its consumers as one aspect of the responsibility of the reader. ${ }^{30}$ For those few readers who do share Trantraal's background, the reading experience must be a very different one - including justifiable pride that their way of speaking, so often denigrated, has been given the prestige of poetry on the page.

29 Wikipedia describes Bishop Lavis as follows: 'It had, as of 2001, a population of 44,419 people, of whom $97 \%$ described themselves as Coloured, and 90\% spoke Afrikaans while 9\% spoke English' < https: //en.wikipedia.org/wiki/Bishop_Lavis> [accessed 27 August 2019].

30 Trantraal has reflected on these disparities in 'Cash for Gold', which begins, 'Ek wonne of ekkie ienagste | prize-winning poet is | wat copper wire | vie kosgeld moet strip' (I wonder if I am the only prize-winning poet who has to strip copper wire for money for food), in Alles het niet kom wôd, p. 42. 


\section{UNTRANSLATABILITY AND THE EXPERIENCE OF TRANSLATION}

I chose this poem, and Trantraal's work more generally, because it foregrounds the question of untranslatability: the conventional model of translation simply does not work in this case. I've written elsewhere about Afrikaans literature that employs forms of the language that are somewhat less resistant to translation (though not without many challenges), ${ }^{31}$ and noted that such works rely on translation to achieve a readership beyond the very small number of Afrikaans readers in South Africa. But in choosing to write in Kaaps, Trantraal and others even more obviously deny themselves a wider readership. This clearly has consequences for any notion of 'world literature' that relies on translation, such as David Damrosch's. Are we to consign all those works written according to linguistic protocols that fall between standard languages to oblivion, as far as any conception of the 'world' is concerned? My preference would be to expand the notion of translation so that it includes a variety of ways of conveying the experience of the original, wherever possible allowing the reader to engage, at least to some degree, with that original and acknowledging the unavoidable force of untranslatability. $^{32}$

31 See Derek Attridge, 'Contemporary Afrikaans Fiction and English Translation: Singularity and the Question of Minor Languages', in Singularity and Transnational Poetics, ed. by Birgit Mara Kaiser (New York: Routledge, 2014), pp. 61-78, and 'Contemporary Afrikaans Fiction in the World: The Englishing of Marlene van Niekerk', Journal of Commonwealth Studies, 49.3 (2014), pp. 395-409.

32 For a study that harnesses the notion of untranslatability in opposing expansionist versions of 'world literature', see Emily Apter, Against World Literature: On the Politics of Untranslatabilty (London: Verso, 2013). 
Translation, instead of being conceived of as the simulation, for the reader competent in one language, of the experience of a reader competent in a different language, would become an open field of varied practices including literal translation, explanation, and suggested equivalents, with the recognition that readers' differing idiolects will mean that different strategies have differing chances of success in different contexts. Stefan Helgesson suggests that the process of retranslation 'contributes to establish not "a" text, but an expandable, multilingual textual zone, issuing from multiple subjectivities, produced in discrete systems of publication, and constituting thereby the effective world-literary existence of a poem or a novel. ${ }^{33}$ This approach would mean dropping the implicit requirement that the translation be roughly the same length as the original and exploiting to the full whatever elements of the original are available to the reader of the translated version. ${ }^{34}$ Derrida has argued that ' $[\mathrm{n}]$ othing is untranslatable, if only one gives oneself the time necessary for the expenditure or expansion of a competent discourse measuring up to the power of the original'. He urges the

33 Stefan Helgesson, 'Translation and the Circuits of World Literature', in The Cambridge Companion to World Literature, ed. by Ben Etherington and Jarad Zimbler (Cambridge: Cambridge University Press, 2018), pp. 85-99 (p. 97).

34 Damrosch discusses three translations of Murakami Shikibu's Book of Genji, pointing out that the increasing number of notes in successive translations significantly enriches the reading experience (What Is World Literature?, pp. 296-97). He quotes André Lefevere: 'When we no longer translate Chinese T'ang poetry "as if" it were Imagist blank verse, which it manifestly is not, we shall be able to begin to understand T'ang poetry on its own terms. This means, however, that we shall have to tell the readers of our translations what T'ang poetry is really like, by means of introductions, the detailed analysis of selected texts, and such', Lefevere, 'Composing the Other', in Postcolonial Translation: Theory and Practice, ed. by Susan Bassnett and Harish Trivedi (London: Routledge, 1999), pp. 79-94 (pp. 77-78). 
renunciation of the ideal of an 'economic equivalence', that is, the traditional demand that the translated work be close to the original in length. ${ }^{35}$ We now have relatively new tools at our disposal in getting to grips with writing in a language with which we're not familiar, including online translation tools such as Google Translate, cloud-based dictionaries, easily accessible background information, and text-to-speech and speech-to-text applications. When J. M. Coetzee published his novel The Death of Jesus first in Spanish translation I was able to read it by using these tools to complement my rudimentary Spanish, alternating between using my phone's camera for instantaneous translation, reading the Spanish aloud to Google, and taking advantage of the handwriting facility.

Translation in this guise would be seen less as a matter of producing an equivalent text in another language and more as working with the original to find ways of enabling access to it. The virtues of partial comprehension of the original, in contrast to complete comprehension of a translation, would be acknowledged. Translation in this sense would be understood as an unending process (and in this respect is akin to Barbara Cassin's untranslatables, which in other respects present a rather different understanding of the working of discrete languages). ${ }^{36}$ If I may be autobiographical again, I recently completed a book on the experience of poetry from Ancient Greece to the Renaissance. This meant working on poems in a number of languages, including Ancient Greek, Latin, Old English, Old French, Occitan, and Medieval Italian as well as

35 Jacques Derrida, Le Monolinguisme de l'autre (Paris: Galilée, 1996), p. 56 (my translation).

36 Barbara Cassin, ed., Dictionary of Untranslatables: A Philosophical Lexicon, trans. by Steven Rendall and others (Princeton, NJ: Princeton University Press, 2014). 
Middle and Early Modern English. My expertise in these languages varies from none to a little to reasonable competence, and I had to rely heavily in places on translations. I found that having more than one translation was very helpful, as were translators' notes, as I could combine the translators' suggestions with my own, often limited, understanding to come up with what I hope was a reasonable grasp of the poem in question - but I have no illusions about the finality or exhaustiveness of that comprehension. (Though this is true of any poem worth reading.)

Such an expansion of the notion of translation shouldn't be confined to works in 'non-standard' languages; if we recognize the artificiality of the standard languages and think in terms of the experience of literature, we're free to experiment across traditional boundaries in seeking to create an experience for new readers that has some degree of resemblance to that of the original readers. Most literary works draw on a range of linguistic usages, implying, for those familiar with them, differences in class, age, location, profession, and so on, and a sense of that range is an important part of the experience of the reader. Finding an equivalent for that range in another linguistic habitat by means of traditional translation is sometimes impossible; other techniques are required. Moreover, different genres require different strategies: the line-by-line commentary I suggested for a short poem isn't going to work for a novel. There is also merit in translations written for those who are at home in the language of the original; Clive Scott has published several books exploring this possibility. ${ }^{37}$

37 See, for instance, Clive Scott, Translating the Perception of Text: Translation and Phenomenology (Oxford: Legenda, 2012); Literary Translation and the Rediscovery of Reading (Cambridge: Cambridge Univer- 
This question of the cultural implications of the original is one that is posed by all translation; the more distant the culture of the writer, the more the reader has to intuit or research in order to appreciate the writing. ${ }^{38}$ Here again, translation may work best if it's not thought of as the transfer of a set of meanings encoded in the words of one language into the words of another, but as an attempt to create, by whatever means appropriate, an experience that corresponds in some measure to the experience of a reader who's able to enjoy the original directly. We can go further: reading virtually any literary work involves some cultural distance, and perhaps some linguistic distance as well, even if it's in a language one knows well - hence the value of annotations of various kinds, including modern 'translations' of words that have changed their meaning over time. There will always be variations in the needs of different readers: every reader brings a singular idioculture to the practice of reading a literary work, whether in a familiar or an unfamiliar language. Over time, this idioculture changes as a result of further experiences, including further reading; to misquote Heraclitus, you can never read the same poem twice. Reading cultures more broadly change too; André Lefevere, presenting the argument that translations refract rather than reflect the original, wrote in 1982: 'Standards have changed so often in the history of Western literature that it must be obvious by now that translations are "good" only with respect to a certain place and a certain time, in certain circumstances.' 39

sity Press, 2012); and The Work of Literary Translation (Cambridge: Cambridge University Press, 2018).

38 See Attridge, Work of Literature, pp. 204-18.

39 André Lefevere, 'Literary Theory and Translated Literature', Dispositio, 7.19/21 (1982), pp. 3-22 (p. 9). 
The experience of reading a work in translation is different only in degree from the reading of works in a language in which one is competent. Most accounts of the practice of reading - I'm thinking, for instance, of the studies that go under the name of 'reader-response theory' as well as the phenomenological tradition - underestimate, to my mind, the complexity of response of which the average literary reader is capable. To read well is to bring to bear on a text as much of one's idioculture as is relevant, which, since relevance can't be known in advance, involves a constant process of testing; it's to keep in play one's awareness that the work one is engaging with is the product of an individual's creative labour; it's to allow a role to whatever knowledge one possesses about the original context within which the work was written; it's to recall where appropriate other works by this author, or works from the same period, or works in the same genre; and it's to relate all this to the needs and values of one's own time. To read a translated work is not substantially different. It is true that one is aware of the creative labour of two individuals - but then many works in their original language bear the traces of more than one author. As Kate Briggs puts it in This Little Art, her superb meditation on the art of translation from the point of view of a practitioner, in reading a translation as a translation, we establish a relationship with two creative projects: 'Not either/or, but holding and maintaining a relation with both writers, a sense of both writing practices, in their shared project and in all the important ways those projects differ, in the head, and somehow together. ${ }^{40}$ (Of course, if one is unaware that one is reading a translation, the experience is no different from reading an original work - and there are commercial reasons for the attempt to

Kate Briggs, This Little Art (London: Fitzcarraldo Editions, 2017), p. 49. 
create this illusion for readers.) It's worth emphasizing that translation, like all forms of commentary, quotation, or reinscription, is one element in the ongoing process that keeps literary works alive. ${ }^{41}$ The singularity of the work is not threatened but constituted by translation - into the idiolectal and idiocultural frameworks of readers, into the words of commentators, and into other linguistic forms.

\section{$* * *$}

What, then, are the consequences of this approach to translation for the concept, and the associated scholarly and pedagogic programme, of 'world literature'? It's a concept that has been found wanting by several commentators, among them Aamir Mufti, Gayatri Spivak, and Emily Apter, ${ }^{42}$ and to my mind these critiques contain much that is cogent and convincing. However, there's no denying the prominence of the idea of world literature in literary studies today, at least in the Anglosphere. Without a commitment to the notion of separate languages, there might be less emphasis on discrete literary traditions and more attention to the fluidity of linguistic and literary practices around the globe. The privileging of standard languages and the communities they are associated with would be challenged by increased attention to so-called 'dialects' and 'multilingual' communities. There might be a greater willingness on the part of writers to employ their own nonstandard speech practices if they could expect a global read-

41 Stefan Helgesson, 'Clarice Lispector, J. M. Coetzee and the Seriality of Translation', uses Sartre's term 'serial collective' to describe the many contributors to a work's continuing vitality, in Translation Studies, 3 (2010), pp. 318-33.

42 See Mufti, Forget English!; Gayatri Chakravorty Spivak, Death of a Discipline (New York: Columbia University Press, 2003); Emily Apter, Against World Literature. 
ership. The pedagogic consequences in courses of 'world literature' might include a greater use of original texts and an awareness of the provisionality of any effort of translation. This is not to take sides in the old 'domestication' versus 'foreignization' debate: there's room for both kinds of translation in this picture. ${ }^{43}$

In The Singularity of Literature and The Work of Literature I proposed an account of literary experience as an encounter with alterity, inventiveness, and singularity, treating these as three aspects of the same event, an event and experience whereby the reader is taken into a space of unfamiliarity that effects a change - which may be mental, emotional, or even physiological. Literary cultures other than that in which I am at home hold out enormous promise for this experience; and rather than seeing translation as a way of remoulding the strange into the familiar, I want to see it as a way of maximizing exposure to the singularity, inventiveness, and alterity of the original. In this way, world literature may be appreciated as the rich and diverse body of creative artefacts that it really is.

43 I also like Briggs's idea that translating challenging texts 'might put new pressures on the English language, forcing the discovery of new, or tapping into old and neglected, resources', This Little Art, p. 30. 
Derek Attridge, 'Untranslatability and the Challenge of World Literature: A South African Example', in The Work of World Literature, ed. by Francesco Giusti and Benjamin Lewis Robinson, Cultural Inquiry, 19 (Berlin: ICI Berlin Press, 2021), pp. 25-56 <https://doi.org/10.37050/ci-19_02>

\section{REFERENCES}

Anderson, Benedict, Imagined Communities, 2nd edn (London: Verso, 1991) Apter, Emily, Against World Literature: On the Politics of Untranslatability (London: Verso, 2013)

- The Translation Zone: A New Comparative Literature (Princeton, NJ: Princeton University Press, 2006) <https://doi.org/10.1515/ 9781400841219>

Attridge, Derek, 'Contemporary Afrikaans Fiction and English Translation: Singularity and the Question of Minor Languages', in Singularity and Transnational Poetics, ed. by Birgit Mara Kaiser (New York: Routledge, 2014), pp. 61-78 <https://doi.org/10.4324/9781315773629-4>

- 'Contemporary Afrikaans Fiction in the World: The Englishing of Marlene van Niekerk', Journal of Commonwealth Studies, 49.3 (2014), pp. 395-409 <https://doi.org/10.1177/0021989414531591>

_ Peculiar Language: Literature as Difference from the Renaissance to James Joyce (Ithaca, NY: Cornell University Press, 1988)

- The Singularity of Literature (London: Routledge, 2004) <https://doi. org/10.4324/9780203420447>

- The Work of Literature (Oxford: Oxford University Press, 2015) <https: //doi.org/10.1093/acprof:oso/9780198733195.001.0001>

Briggs, Kate, This Little Art (London: Fitzcarraldo Editions, 2017)

Carstens, Wannie A. M., and Edith H. Raidt, Die Storie van Afrikaans: Uit Europa en van Afrika (Pretoria: Protea Boekhuis, 2017)

Cassin, Barbara, ed., Dictionary of Untranslatables: A Philosophical Lexicon, trans. by Steven Rendall and others (Princeton, NJ: Princeton University Press, 2014) <https://doi.org/10.1515/9781400849918>

Chambers, J. K., and Peter Trudgill, Dialectology, 2nd edn (Cambridge: Cambridge University Press, 1998) <https://doi.org/10.1017/ CBO9780511805103>

Damrosch, David, What Is World Literature? (Princeton, NJ: Princeton University Press, 2003) <https://doi.org/10.1515/9780691188645> 
Derrida, Jacques, Le Monolinguisme de l'autre (Paris: Galilée, 1996)

—_ 'Two Words for Joyce', in Post-structuralist Joyce: Essays from the French, ed. by Derek Attridge and Daniel Ferrer (Cambridge: Cambridge University Press, 1984), pp. 145-59

Grobbelaar, Peter, ed., Reader's Digest Afrikaans-Engels Woordeboek/EnglishAfrikaans Dictionary (Cape Town: Reader's Digest Association, 1987)

Harrison, Nicholas, 'World Literature: What Gets Lost in Translation?', Journal of Commonwealth Literature, 29 (2014), pp. 411-26<https://doi.org/10. $1177 / 0021989414535420>$

Helgesson, Stefan, 'Clarice Lispector, J. M. Coetzee and the Seriality of Translation', Translation Studies, 3 (2010), pp. 318-33<https://doi.org/10. $1080 / 14781700.2010 .496929>$

'Translation and the Circuits of World Literature', in The Cambridge Companion to World Literature, ed. by Ben Etherington and Jarad Zimbler (Cambridge: Cambridge University Press, 2018), pp. 85-99 <https:// doi.org/10.1017/9781108613354.007>

Joubert, Marlise, ed., In a Burning Sea (Pretoria: Protea House, 2014)

Kamfer, Ronelda, Hammie (Cape Town: Kwela Books, 2016)

Noudat slapende honed (Cape Town: Kwela Books, 2008)

Lefevere, André, 'Composing the Other', in Postcolonial Translation: Theory and Practice, ed. by Susan Bassnett and Harish Trivedi (London: Routledge, 1999), pp. 79-94

— 'Literary Theory and Translated Literature', Dispositio, 7.19/21 (1982), pp. 3-22

Lennon, Brian, In Babel's Shadow: Multilingual Literatures, Monolingual States (Minneapolis: University of Minnesota Press, 2010) <https://doi.org/ 10.5749/minnesota/9780816665013.001.0001>

Mesthrie, Rajend, ed., Language in South Africa (Cambridge: Cambridge University Press, 2002) <https://doi.org/10.1017/CBO9780511486692>

Mufti, Aamir R., Forget English! Orientalisms and World Literatures (Cambridge, MA: Harvard University Press, 2016) <https://doi.org/10.4159/ 9780674915404>

Sakai, Noaki, 'How Do We Count a Language? Translation and Discontinuity', Translation Studies, 2 (2009), pp. 71-88 <https://doi.org/10.1080/ $14781700802496266>$

Scott, Clive, Literary Translation and the Rediscovery of Reading (Cambridge: Cambridge University Press, 2012)

- Translating the Perception of Text: Translation and Phenomenology (Oxford: Legenda, 2012)

The Work of Literary Translation (Cambridge: Cambridge University Press, 2018) <https://doi.org/10.1017/9781108678162>

Small, Adam, Kitaar my Kruis (Cape Town: Hollandsche Afrikaansche Uitgewers Maatschappij, 1973)

Spivak, Gayatri Chakravorty, Death of a Discipline (New York: Columbia University Press, 2003) 
Steiner, George, After Babel: Aspects of Language and Translation, 3rd edn (Oxford: Oxford University Press, 1998)

Trantraal, Nathan, Alles het niet kom wôd (Cape Town: Kwela Books, 2017)

- Chokers en survivors (Cape Town: Kwela Books, 2013)

Oolog (Cape Town: Kwela Books, 2020)

Wit issie ' $n$ colour nie (Cape Town: Kwela Books, 2018)

Van Heerden, Menán, 'Afrikaans: The Language of Black and Coloured Dissent', South African History Online <https://www.sahistory.org.za/ article/afrikaans-language-black-and-coloured-dissent> [accessed 27 August 2019]

Van Niekerk, Marlene, Die Kortstondige raklewe van Anastasia W (TEATERteater, 2010)

Walkowitz, Rebecca L., Born Translated: The Contemporary Novel in an Age of World Literature (New York: Columbia University Press, 2015) <https: //doi.org/10.7312/walk16594>

Weber, Samuel, 'A Touch of Translation: On Walter Benjamin's “Task of the Translator"', in Nation, Language, and the Ethics of Translation, ed. by Sandra Bermann and Michael Wood (Princeton, NJ: Princeton University Press, 2005), pp. 65-78 <https://doi.org/10.1515/9781400826681. 65>

Young, Robert J. C., 'That Which Is Casually Called a Language', PMLA, 131.5 (2016), pp. 1207-21 <https://doi.org/10.1632/pmla.2016.131.5. 1207> 